This is an AM (Accepted Manuscript)-version of the paper. Please cite the published version.

Jonas Stein (2019) The local impact of increased numbers of state employees on start-ups in Norway, Norsk Geografisk Tidsskrift - Norwegian Journal of Geography, DOI:

10.1080/00291951.2019.1644369

\title{
The local impact of increased numbers of state employees on start-ups in Norway
}

\section{Abstract}

This study assesses the impact of concentrations of state employees on local growth and development. Local multiplier effect theory suggests that the increased local demand of state employees, especially highly skilled employees, would stimulate the local supply of goods and services and, hence, local development. However, other theories of regional development have shown that factors such as having a university or city size might also explain why some municipalities with a high percentage of state employees grow faster than others.

By applying a multilevel panel data analysis of 417 Norwegian municipalities from 2006 to 2014, this study finds no effect of the percentage of state employees on local development, measured in terms of the relative number of start-up firms or population growth. While there is a small positive effect of state employees in the bivariate model, there is no significant effect of state employees on local development when controlling for relevant factors like municipality size or universities. This finding suggests that the relocation of state employees is a rather limited tool for stimulating local and regional growth; if applied, policymakers should consider how the relocation could stimulate place-sensitive development in individual municipalities.

Keywords: State employees, Start-ups, Development, Norway, Universities 


\section{Introduction}

Like many other governments, the Norwegian government has designed a variety of policies to promote place-based and regional development (Stein, 2019; Teigen, 2011). One such policy is the relocation of public sector employees as a tool to help address employment problems in areas marked by economic decline (Kiland and Trondal, 2010; Trondal, 2011). The aim is to use state employees as actors contributing to economic growth and development. They can do so in two ways; first, based on a local multiplier effect theory, new public jobs create additional local jobs as a result of the increased demand for locally produced goods and services (Moretti 2010). Second, inspired by cluster theory, state employees potentially bring knowledge production and collaboration with diverse stakeholders for local development (Porter 1998; Reve 2009).

The positive contributions of this policy are more or less taken for granted by policymakers, who have rolled out this type of policy in many different countries, including the United Kingdom, Sweden, Denmark, and Norway (Kommunaldepartementet, 2017; Lyons, 2004; Sjöstedt Landén, 2012). There have been few academic studies of the effect of these policies, however, and the only major work on the local effects, especially on the labor market, is that of Faggio (2016), who examined the effects of the relocation of state employees in the UK based on the Lyons Inquiry. She found a small, positive local effect of relocating state jobs. When using English data at the local authority level for 2003-2007, however, Faggio and Overman (2014) found that public sector employment had no identifiable effect on total private sector employment. As the Faggio (2016); Faggio and Overman (2014) studies have only focused on the United Kingdom, it would be of academic interest to explore the local effect of these types of policies in other countries.

The main argument for choosing one country when studying the effect of specific policies is that other unobserved, country-specific institutional and structural variables are similar for all of the units affected by the policies. Consequently, the study of the effects of policies in a single unit could aim to later be generalized across a larger set of units (Gerring 2004). The Norwegian government has relocated and established state agencies around the country to stimulate local development (Kommunaldepartementet 2017). Nevertheless, scholarly work on the relocation of state agencies in Norway is relatively scarce; the majority has been reviewed in an anthology edited by Trondal (2011). In particular, Sætren (1983) and Kiland and Trondal (2010) conducted important work on the various political processes involved in moving state agencies out of Oslo, the national capital. Egeberg and Trondal 
(2011) showed that agency autonomy, agency influence, and inter-institutional coordination seem to be relatively unaffected by the agency site. However, no previous study has investigated the local impact of public sector relocation policies in Norway, although a consultant report ordered by the government has made some generalized estimates about some smaller positive local effects of the 2003 relocation (Fornyingsdepartementet 2009).

Closely related to the work of Faggio (2016), this article studies the local effects of the relocation of state jobs in Norway as a tool for local development. The Norwegian case is of interest to the general literature, as relocation has been on the political agenda for more than 40 years (Arbeidsdepartementet 2003; Fornyingsdepartementet 2009;

Kommunaldepartementet 2017; Sætren 1983, 2011). Combined with good, consistent, municipal-level data, this analysis allows for longitudinal and comparative analyses. In addition to providing information on the Norwegian case, it contributes to the general literature on the effects of relocating public sector workers and the growing literature on the evaluation of place-based government policies.

In analyzing these problems, empirical information was gathered for one million Norwegian state employees from 2006 to 2014 from the open registry at the Norwegian Centre for Research Data. By aggregating this information to the municipal level, each municipality receives an annual score of the number of state employees. Together with other relevant data, this data was then used to create a panel data set of 417 Norwegian municipalities (see the Supplementary Appendix for details about the data). Based on an analysis of the collected data, the article aims to answer the following question: Does having a high percentage of state employees in a municipality have any effect on local development? There are many ways to measure local development and the repercussions of government policies. In this study, the main dependent variable is the number of startup firms per 1,000 inhabitants in each municipality as a dependent variable. It is a good proxy variable for both economic and demographic development, because it measures the increased concentration of economic activity (Audretsch and Fritsch, 1994), as well as how local, regional, and national actors perceive the future local development in the municipality. Studies have found a correlation between local development and the number of start-up firms (Audretsch and Fritsch, 1994; Kane, 2010). The same models are also run with population growth in the municipality as an alternative dependent variable for local development. These models display similar findings, as they run with start-ups as the dependent variable. 


\section{Conceptual framework}

The start-ups-local development relationship

There is a vast literature measuring development (see discussion in Pike, Rodríguez-Pose, \& Tomaney, 2007). Despite flaws and inaccuracy, GDP per capita has historically been a relatively good estimate of national or regional development due to its correlation with other social- and economic-development indicators (Diener and Suh, 1997). When analyzing smaller spatial units, like municipalities, there is no such indicator.

In the 1990s and 2000s, literature emerged connecting entrepreneurial activity to growth and development, typically measuring economic performance in terms of firm growth and survival (Audretsch, 1995; Caves, 1998; Davidsson, Delmar, \& Wiklund, 2006). The compelling stylized fact emerging from this literature is that entrepreneurial activity is positively related to growth, findings which hold across Western economies and time periods (Carree and Thurik, 2010).

A small body of literature developed linking measures of regional entrepreneurial activity to economic performance (Acs and Armington, 2004; Audretsch and Fritsch, 2002), finding that differences in levels of entrepreneurial activity are positively associated with variation in growth rates. The relationship is mutually reinforcing: If the city or region is growing, the demand for goods and services increases, and new firms will supply some of this increased demand. If the city or region is characterized by an entrepreneurial spirit, more entrepreneurs are attracted to the city and region, and they develop new start-up firms, all of which leads to growth.

Based on this literature, it seems logical that a local community that is developing and growing will have a higher percentage of start-up firms than communities in stagnation or decline.

\section{Theories on the benefits of public sector employment}

The basic assumption of the effect of public sector workers relates to the local multiplier effect, as described by Moretti (2010): Every time a local economy generates a new job by attracting new businesses in the traded sector, a significant number of additional jobs are created in the non-traded sector. Moretti and Thulin (2013) found that the multiplier effect was particularly large for jobs with high levels of human capital and high-technology industries. These findings are important for local development policies, as they suggest that 
municipalities in general and the goal of increasing local employment in particular should target high-tech employers with high levels of human capital. The non-tradable sector may supply intermediate goods and services to the public sector, meaning that increased public sector employment directly increases demand (Faggio and Overman, 2014).

Another potential, positive effect could be found in cluster theories, which emphasize the need for building cities and regions around their core comparative advantage (Maskell, 2001; Porter, 1998, 2000; Reve, 2009). According to Porter (1998), clusters are geographic concentrations of interconnected companies and institutions in a particular field. They are defined by critical masses - in one place - of unusual competitive success in particular fields. Clusters are a striking feature of virtually every national, regional, state, and even metropolitan economy, especially in more economically advanced nations. Strong clusters potentially lead to synergies in which new start-up firms are created in the intersection between the public and private sectors.

The argument that new public sector jobs, especially those involving high levels of human capital, could be beneficial for the public and private sectors by generating synergies and a larger pool of workforce builds on cluster and human capital theories (Berry and Glaeser, 2005; Hoyman and Faricy, 2009). Both in the service and knowledge economies, human capital has been proven to correlate with urban growth (Barro, 2001; Black and Lynch, 1996). If there is already a local cluster in the same or similar field in which a public agency is working, this could lead to an enlargement of the local cluster and, hence, local development. Eriksson, Lindgren, \& Malmberg (2008) find that the concentration of similar activities may be useful for small regions. A positive relationship between government and industry is seen as one of the keys in triple-helix theory for innovation (Etzkowitz and Leydesdorff, 2000; Leydesdorff, 2012). Furthermore, new public employees are skilled workers who may also bring in partners who often tend to have high levels of human capital. Growth in the number of state employees could therefore have positive economic repercussions and stimulate local development and business creation. As seen above, there are theoretical arguments for why higher numbers of state employees could stimulate local development, as formulated in the following hypothesis:

H1: There is a positive effect of the percentage of public sector workers on the number of start-up firms. 


\section{Countertheories}

But there are also counterarguments regarding the positive effects of increased public employment. Burdett (2012) showed that public sector employment crowds out private sector employment in regions where public pay is higher than its counterpart outside the region. Contrastingly, in regions where private employers pay the same or better as the public sector, an increase in public sector workers raises total employment, leading to a multiplier effect.

And although there are concepts and theories about the effect of increasing the number of public sector workers, there are other factors that also influence the creation of new firms. In contrast to theories about self-determination and exogenous growth theories, there are other - more general - theories for growth (for a broader review see Pike, et al., 2007). Geography and physical nature put important restrictions on local development (Sheppard 2011). New economic geography theories focus on core economic agglomerations and urban regions, socalled spatial spikes, as dominant factors for regional development, indicating that city size and urbanization are much more important for local development (Brakman, Garretsen, \& Van Marrewijk, 2009; Scott and Storper, 2005). These more general theories and trends could render the local effects of more state employees insignificant. More recent studies have also emphasized the need for regional development strategies to be specifically tailored to the conditions of every territory by the implementation of place-sensitive policies (Iammarino, Rodriguez-Pose, \& Storper, 2018; Rodríguez-Pose and Ketterer, 2019).

There is also the possibility that the effect of state employees is confounded by other effects. Many state employees in Norway are employed by large universities, and this potential confounding effect should be controlled for in the model-building. Both theoretically (see reviews in Arbo and Benneworth, 2007; Drucker and Goldstein, 2007) and empirically (Drucker and Goldstein, 2007; Goddard and Chatterton, 1999; Mellander and Florida, 2011), there are studies investigating the impact of universities on regional development. University activities, particularly knowledge-based activities, such as teaching and basic research, have been found to have substantial positive effects on a variety of measures of regional economic progress (Drucker and Goldstein, 2007). Mellander and Florida (2011) showed that universities play the most important role across the board for regional wages and development. This is in line with the findings of Berry and Glaeser (2005) and Florida (2005). Benneworth and Nieth (2018) summed up the main theoretical arguments on the role of universities in regional development from an institutional perspective: First, universities can be actively involved in defining the parameters of regional strategies due to their detailed knowledge of gaps and opportunities. Second, they can be important contributors to regional 
capacities regarding institutional and social attributes. A third element is that universities also contribute to smart specialization policies (Foray, David, \& Hall, 2009; McCann and OrtegaArgilés, 2011) through the creation of external connections outside the immediate innovation system. Studies have also shown that start-up firms tend to be more geographically localized than other outcomes of university knowledge production (Candell and Jaffe, 1999). Other studies have explored the relationship between universities and the emerging number of spinoff firms from universities (e.g. Brett, Gibson, \& Smilor, 1991; Feller, Ailes, \& Roessner, 2002; Smilor, Gibson, \& Dietrich, 1990; Steffensen, Rogers, \& Speakman, 2000).

Finally, it is possible that despite the political rhetoric about the relocation of state employees as a tool for stimulating local and regional development, it is more motivated by other political goals such as curbing political tensions in the society. Jennings and Stoker (2016) reveal how many countries are experiencing uneven development and their citizens are increasingly split between those who can access high-skill jobs and those who cannot. Consequently, some citizens are living in cosmopolitan areas of growth, others in backwater areas of decline. This divide between different parts of the country can have significant political effects (e.g. Lee, Morris, \& Kemeny, 2018; Rodríguez-Pose, 2018), which in turn could explain some of the political motivation to relocate and create state employment in peripheral regions. Economic redistribution - in this case, through public sector workers - is also a tool for generating cohesion and loyalty from peripheral territories to the capital and the state; it is a necessary instrument for guaranteeing the continued supremacy of the political center and, hence, for maintaining political stability (Rokkan and Urwin, 1983, 173). Given that public sector and university employees are a necessary cost for the state, the relative cost of locating some of them in peripheral regions is not very high for policymakers. Creating new jobs dealing with new government tasks is not much more expensive outside of the center and is a political win among the actors in the periphery.

Instead of understanding the relocation of public sector workers as a tool for generating regional economic development, it might be more useful to approach it as a political solution for a political problem in the aim to address the center-periphery tension within the political system (Lipset and Rokkan, 1967; Rokkan, 1987; Rokkan and Urwin, 1983). Moving public sector workers allows politicians to provide a specific and visible solution to the center-periphery tension at a relatively small net cost. 


\section{Relocation - the Norwegian case}

As argued by Eckstein (2000), finding crucial cases is essential in social science. According to George and Bennett (2005), Eckstein’s notion of a crucial case is similar to what Lijphart (1979) described as a theory-confirming or theory-infirming case study. In Norway, both the relocation of public sector workers and the establishment of universities and university city colleges have been utilized, partly intended to promote local and regional development. If there are any local or regional effects of relocating state employees or of establishing universities, they should be distinguishable in Norway.

Even though much of the public debate in Norway has been about relocating public sector workers (Sætren 2011), the ability of government to choose between establishing new agencies and creating new public sector work in lagging regions is worth considering. The creation of new public sector jobs in peripheral regions is much less controversial than the relocation of existing old jobs. In the latter case, someone must pay the price - already existing state employees - which can be rather steep on the personal level in some cases (Sjöstedt Landén, 2012). In particular, resistance from within the state bureaucracy is the major reason for the failure of the first two Norwegian relocation programs (1960-72, 19731981), according to Sætren $(1983,2011)$. After the last failure, the new government strategy for 1981-2002 consisted of mainly establishing new public sector jobs in regions outside Oslo. Large state agencies (e.g. the National Registry) were established in Brønnøysund in 1980, and the National Collection Agency was established in Rana in 1990.

In 2003, the Norwegian government launched its third relocation program, which proved successful: roughly 1,000 jobs in seven different agencies were moved from Oslo to five other regions (Arbeidsdepartementet 2003). This was the first time a Norwegian government was able to pass a legislation in Parliament resulting in the transfer of substantial numbers of state employees from Oslo to other parts of Norway. Two particular factors contributed to the success of this policy: First, an unusual political process in which the internal and external opponents of relocation were held at arm's length (Kiland and Trondal, 2010); second, all Norwegian regions benefitted from the relocation program, ${ }^{1}$ providing local and regional pressure on Member of Parliaments on both sides of the aisle to pass the legislation (Saba 2011).

\footnotetext{
${ }^{1}$ Eastern Norway (Norwegian Media Authority and Norwegian Directorate for Civil Protection), Southern Norway (Norwegian Post and Telecommunications Authority), Western Norway (The Norwegian Competition Authority and Norwegian Maritime Authority), Trondelag (Norwegian Labour Inspection Authority), Northern Norway (Civil Aviation Authority).
} 
The three main arguments for relocation were increased agency independence, reduced expenditure, and the development of regional centers (Arbeidsdepartementet 2003). As shown by Egeberg and Trondal (2011), location seems to matter little for Norwegian government agencies, and the evaluation after the relocation program concludes that expenditure has not been reduced (Fornyingsdepartementet 2009). The concern, then, is determining the regional effects of relocation. The minister responsible for the relocation program in Norway was a former economics professor known for his enthusiasm for cluster theories (e.g. Norman and Venables, 2004). As seen in the theoretical section, there are arguments in cluster theory for using the relocation of state employees to strengthen and develop regional and local clusters. In two white papers on Norwegian relocation plans, regional development is seen as a key argument for relocation (Fornyingsdepartementet 2009; Kommunaldepartementet 2017).

The expansion of higher education has been one of the major factors for establishing new state jobs outside the capital; establishing new universities and new student places has been motivated by the need for a more skilled workforce as well as regional development (Elenius, Tjelmeland, Lähteenmäki, \& Golubev, 2015; Fulsås, 1993; Skodvin, 1997; Wikhall, 2001). The establishment of Norwegian universities and their geographical dispersion is also partly the result of regional policies inspired by the Swedish university sector (for more on regional effects in Sweden see Westlund, 2004; Wikhall, 2001). This is especially true in the case of the University of Tromsø, established in 1968 partly to stimulate regional development in the lagging region in Northern Norway (Fulsås 1993). University city colleges have also been dispersed across the country, particularly aimed at facilitating cooperation with local and regional businesses to stimulate growth through innovation and skilled personnel (Skodvin 1997). Overall, Norway is a good case for examining the local effects of state employees in general and highly skilled state employees in particular.

\section{Methods and data}

For their analysis of the effects of public sector workers in the UK, Faggio and Overman (2014) and Faggio (2016) chose the local authority level in the UK. For the study of Norway, the municipality level is more appropriate. There are more than 400 municipalities in Norway, which allows for a sufficient number of level-2 units in the multilevel models (see Stegmueller 2013 for a discussion). It is possible to assume that each municipality is not only a competitive economic unit, using labor to produce goods in the national market, but also a political entity, where the city council and mayor lobby the national and regional governments 
for the relocation of public sector workers (see Trondal 2011). Some municipalities have been more successful in this than others (Fig. 1). There is therefore variation in public sector workers in Norwegian municipalities influenced by local and national policies.

The dependent variable is the number of start-up firms from 2006 to 2014 in Statistics Norway figures. They define a start-up firm as all newly registered firms in all fields of business, except those in public administration, agriculture, forestry, and fishing. ${ }^{2}$ Using the number of start-up firms per 1,000 inhabitants in each municipality has two main advantages. First, the number of new firms is a good proxy variable for economic activity as well as local development; if a municipality is developing, more entrepreneurs will create new companies to meet the expected future demand for all kinds of goods and services. Studies like those of Kane (2010) and Audretsch and Fritsch (1994) have shown startup firms to be a good proxy for local job creation and local economic development. Second, it is possible to create a relative measure for each municipality by dividing the number of new firms by the number of inhabitants, which avoids penalizing small municipalities for having fewer new firms.

To create a balanced panel, the analysis is restricted to the period 2006-2014, which is also near the period when Norway implemented its relocation program (while the decision was passed in 2003, much of the relocation was first effectuated in 2006/07 (Fornyingsdepartementet, 2009, 22-29). To control for differences in relative municipality size and relative impact, the dependent variable is measured as start-up firms per 1,000 inhabitants.

To assess the hypothesis, a panel data set is created and a multilevel time-series analysis applied. All of the models are run by the program $\mathrm{R}$ using the nlme package for multilevel modeling (Pinheiro, Bates, DebRoy, Sarkar, \& Team, 2013). Each municipality $i$ is measured in every year $t$. The base model contains a control for trend with the variable trend.

Level 1: $\quad \gamma$ startup $_{\mathrm{ti}}=\pi_{0 \mathrm{i}}+\pi_{1 \mathrm{i}}$ trend $_{\mathrm{ti}}+\mathrm{e}_{\mathrm{ti}}$

Level 2: $\quad \pi_{0 \mathrm{i}}=\beta_{00}+\mathrm{u}_{0 \mathrm{i}}$

$$
\pi_{1 \mathrm{i}} \text { trend }_{\mathrm{ti}}=\beta_{10}+\mathrm{u}_{\mathrm{ti}}
$$

To operationalize the independent variable of public sector workers, data is used from The Norwegian State Administration Database (NSD 2018), where the municipal localization of $1,152,909$ employees in the Norwegian state from 2006 to 2014 is used to create an

\footnotetext{
${ }^{2}$ https://www.ssb.no/en/statbank/table/06104/?rxid=97ff0130-0c29-43eb-93bc-3da7011cb804
} 
independent variable ${ }^{3}$. Once again, to evaluate the relative impact, the number of state employees is operationalized as the percentage of the number of inhabitants in each municipality for each year. To assess the relative importance of universities, a dummy variable for university cities (Oslo, Bergen, Trondheim, Tromsø, Stavanger, Ås, and Kristiansand) is used to control for the effects of universities on local economic growth.

If city growth is correlated with city size, controlling for city size will be important to avoid a misleading inference about the true impact of the public sector on start-up firms. In the context of cities, the existence of a correlation between city growth and size remains contentious (Gabaix and Ioannides, 2004). However, there is a new idea in economic geography and theories about the creative class (Florida 2005) that urbanization toward larger cities is a major driver for growth and business creation. To control for city size, the municipality population is transformed logarithmically as an independent variable.

The second set of controls includes the municipality share of the working-age population (25-66-year-olds) and its unemployment rate. For both variables, the annual values are based on counts at the end of each month. The unemployed are categorized as people registered as job seekers at employment offices and are unemployed for two weeks. Finally, the effects of the global financial crisis are considered as a dummy variable for the years 2008 and 2009 (for a more detailed description of all variables, see the Appendix).

Even though the reported models are run without lagged variables, models with lagged variables of both percentage of state employees in the municipality and percentage of university and university city college employees in the municipality have also been run, showing similar results as those reported. Finally, there are arguments for using other dependent variables for regional development. In addition to running the models on start-up firms, the models are also run on another popular variable for local development: population growth (for more details on the data, see the Supplementary Appendix).

\footnotetext{
${ }^{3}$ In 2014 2.97\% of the Norwegian population were state employees
} 


\section{Results}

Descriptive statistics

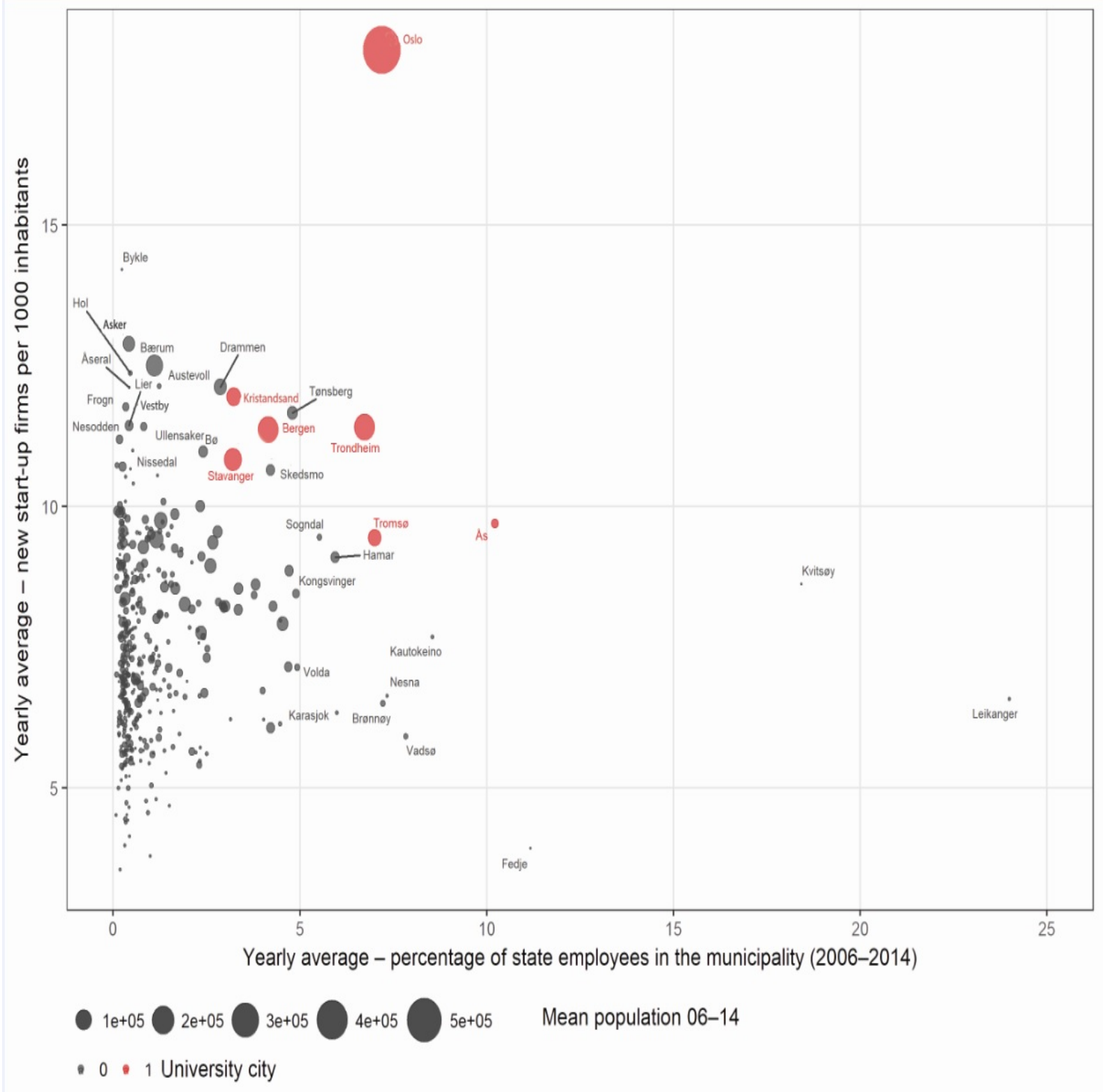

Figure 1 shows the yearly average number of new start-up firms per 1,000 inhabitants in each municipality in Norway from 2006 to 2014. The x-axis indicates the percentage of state employees in the municipality. University cities are marked in blue. 


\section{Regression model}

Table 1: Multilevel regression analysis on the effect on start-ups 2006-2014

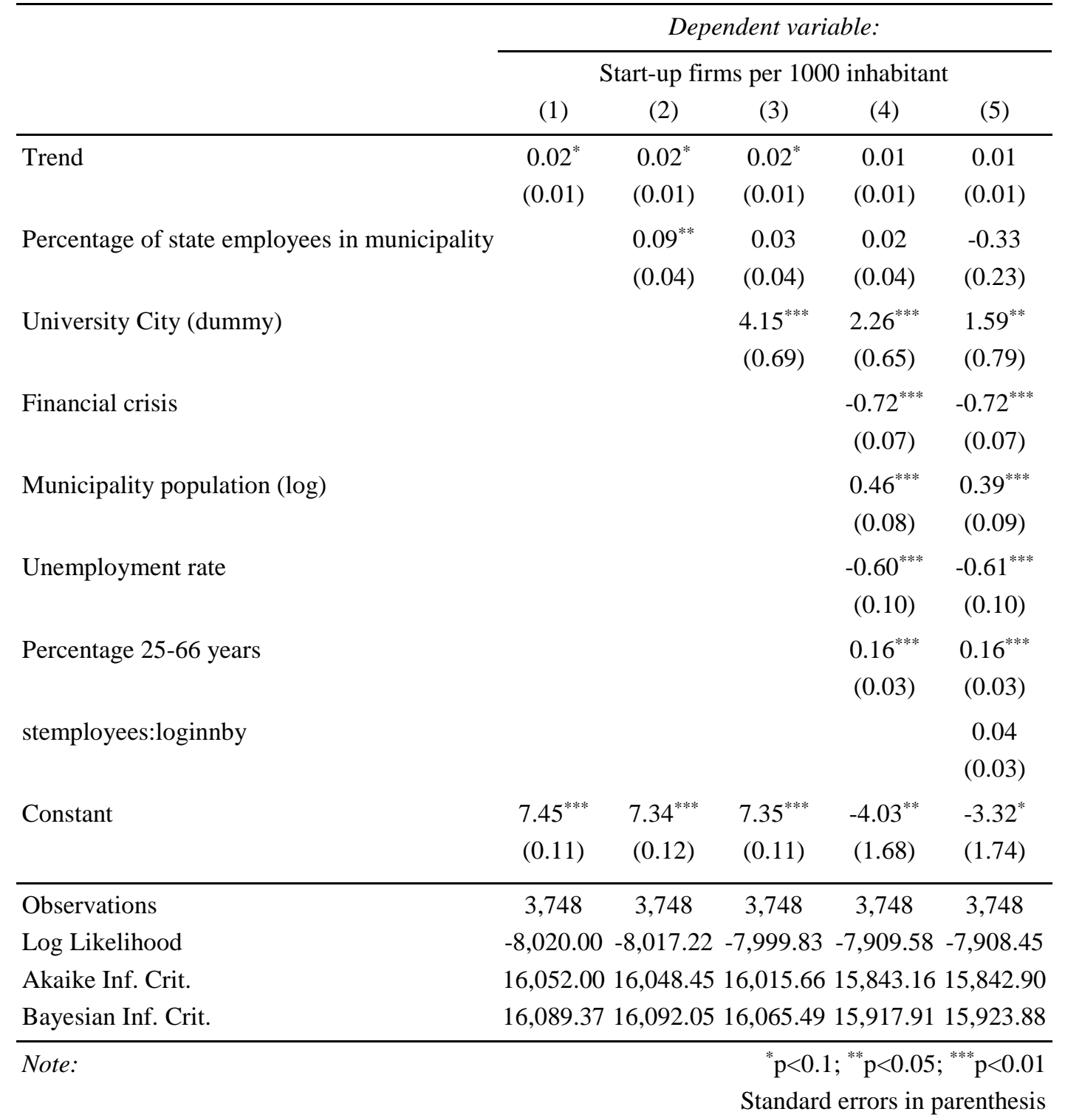

The regression analysis starts with the base model described in Section 4 and shows a small positive trend toward greater business creation. In model 2 (Table 1), the effects of state employees in a municipality and university are added to the analysis. The effect of state employees is generally positive. Model 3 (Table 1) controls for university cities. There is a large, significant effect of universities, but the control variable also renders the effect of state employees insignificant. In model 4 (Table 1), more control variables are added to the analysis. As expected, the financial crisis, city size, unemployment rate, and the percentage of people aged 25-66 all have a significant effect on the number of new firms per 1,000 inhabitants. It is also worth noting how the effect of state employees in this model is close to zero. In the final model, model 5 (Table 1), there is a small positive effect of the interaction 
term between the percentage of state employees and the city population, indicating that there could be some positive interaction effects between larger city size and more state employees. However the effect is not statistically significant.

Table 2: Multilevel regression analysis on the effect on population growth 2007-2014

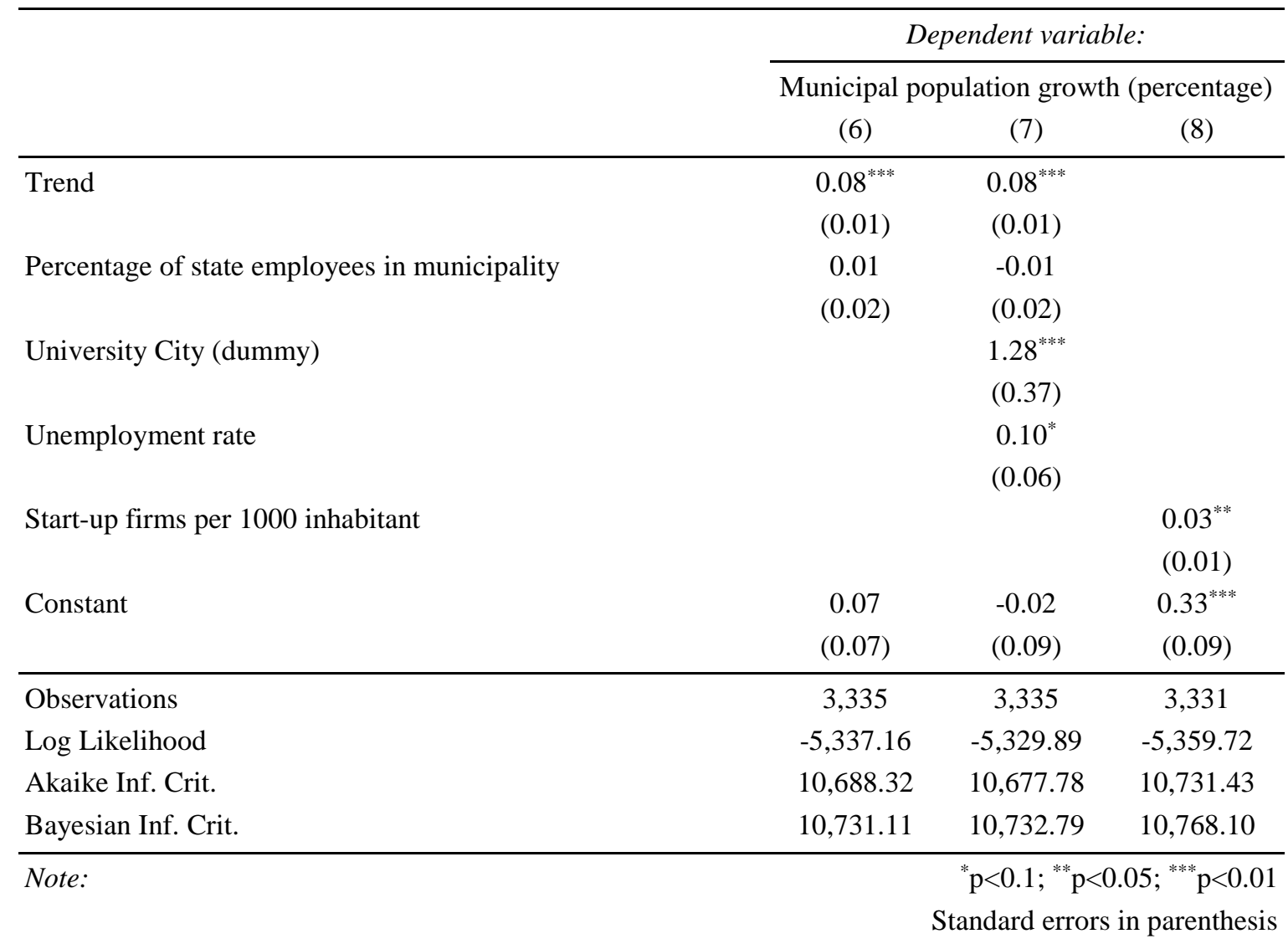

All of the reported models are estimated by the maximum likelihood procedure (ML). They have also been run with restricted maximum likelihood procedure (REML), which produced the same results. In the model-building, the decreasing AIC and BIC show that every model is a better fit for the data. As always with the panel data, there is a potential autocorrelation problem. To deal with this, all of the error terms of the models are corrected with an AR1 structure, which more or less removed the autocorrelation. There is a small autocorrelation of .06 for the first lag in the final model, which could lead to the slight overestimation of the results.

To control for the results in Table 1, the base model is run on population growth. As seen in models 6 and 7 (Table 2), there is no effect on having more state employees in a municipality and the population growth of the municipality. Model 8 merely reveals a significant relationship between the percentage of start-up firms in a municipality and population growth. 
As seen in the conceptual framework, this indicates that the number of start-ups is a relevant indicator of growth.

\section{Discussion}

Based on the regression models (Tables 1 and 2), H1, suggesting that there is a positive effect of increased public sector workers on local development, must be rejected (regardless of whether local development is measured as the relative percentage of start-up firms or in terms of population growth). While there seems to be a small positive effect of state employees in model 2, the effect of state employees in the municipality is even more insignificant when relevant controls are added, and the coefficient is close to zero (model 4). As seen in the conceptual framework, there is a theoretical argument explaining how an increase in public sector employees could crowd out the private sector (Burdett 2012). Although one could be tempted to conclude that the effect is negative, a cautious conclusion would be that the effect of increased public sector employees is neutral.

Cluster theories emphasize that public sector workers might have a positive effect on local development if the municipality is large enough to build larger clusters around it (Maskell, 2001; Porter, 1998, 2000) or a concentration of similar activities (Eriksson et al. 2008). The regression analysis (model 5) shows that the interaction variable between state employees and the municipality population is positive, meaning that state employees could have a positive effect on the development of municipalities that manage to create real cluster synergies. However, the positive effect is not significant at the .05 level ( $p=0.13$ ). This suggests that if there are cluster effects, they are not very strong in the case of Norway or that the relocation of state employees or creation of state jobs has not necessarily been used to create local clusters or local concentration.

As discussed by Sætren (2011) and Saba (2011), one of the reasons for the success of the 2003 Norwegian relocation program was that all of the regions benefitted from it. The decisive argument seems to be the center-periphery tension, where all of the peripheral regions could forge a broad peripheral alliance against the center to gain concessions (Rokkan and Urwin, 1983). Consequently, not all relocations have been designed to build strong clusters. The assessment report in 2009 (Fornyingsdepartementet 2009) asserts that the relocations were easier in some of the larger municipalities, where agencies could recruit from a broader base and create synergies within the municipalities. The relocation of The Norwegian Competition Authority to Bergen and of the Norwegian Maritime Authority to Haugesund stand out as the only examples of successful relocations; these agencies had the 
same qualifications to solve their assignments subsequent to relocation. In the other cases, "relocation has to lead to partial paralyzation of critical social infrastructure and in all cases no reduced overall costs for the government” (Fornyingsdepartementet 2009, 84).

The general models (Table 1) bear important similarities to the findings in the more specific case studies of earlier Norwegian relocation programs (Trondal 2011). If there is a case for creating or relocating state employees, it requires a certain municipality size and, preferably, academic institutions to educate a relevant supply of labor. However, newer relocalizations in Norway seem to be motivated more by that which Rokkan (1987) described as the center-periphery political tension than by ideas of creating regional development through stronger clusters.

As seen in the conceptual framework, this could illustrate some of the challenges involved in the relocation of state employees. Even though politicians would speak about the benefit for local development, there might be other motives behind relocation programs. Instead of understanding the relocation of public sector workers as a tool for generating regional economic development, it might be more useful to approach it as a political solution for a political problem aimed at addressing the center-periphery tension within the political system (Lipset and Rokkan, 1967; Rokkan, 1987; Rokkan and Urwin, 1983); a tension that is clear in many studies of contemporary political issues (e.g. Jennings and Stoker, 2016; Lee, et al., 2018; Rodríguez-Pose, 2018). Moving public sector workers allows politicians to provide a specific, concrete solution to the center-periphery tension at relatively little net cost. Although previous studies do not find that relocation has reduced public spending, spending has not increased. The workers who must relocate are the ones shouldering the greatest cost. As seen by Sjöstedt Landén (2012), the individual cost of relocation could mean being forced to rethink life and work and having to re-identify with professional positions. Studies find that only $10-15 \%$ choose to relocate (Fornyingsdepartementet 2009); in many cases, these are highly qualified workers who are able to find alternative employment in the capital.

This analysis has some limitations. It is limited to Norway, and a more thorough analysis would add more countries to provide a comparative perspective. As with all of these analyses at the municipality level, there is the risk of ecological fallacy. A study at the individual level might also be useful to explore this issue and to identity potential success stories and failures. Finally, another way to conduct this study could be to use the synthetic control method proposed by Abadie, Diamond, \& Hainmueller (2015). Based on a donor pool of comparable cases, they use statistical inferential techniques to construct a synthetic version of the unit of study based on the weighted average of most similar cases, chosen by statistical 
data. This allows for a synthetic version of the cases in question that could be compared to the original case. This alternative method could be used in future studies of the effects of relocating state employees.

\section{Conclusions}

This study aimed to determine whether the effect of state employees was positive for local and regional development. Based on the models, a relationship between a high percentage of public sector employees in a municipality and the number of new start-up firms seems to be non-significant. The finding is similar when using population growth as an alternative measurement for local development. However, even when controlled for city size, unemployment rate, demographic characteristics, and larger national and global trends (financial crisis), university cities have a significant, positive effect on the number of startups.

The relocation of public sector workers seems to be a rather popular policy for promoting place-based and regional development. Some of the arguments used for this kind of policy seem questionable. In the case of Norway, there is no indication of reduced public spending (Fornyingsdepartementet 2009) or increased agency independence (Egeberg and Trondal, 2011). This study also showed that the extended local and regional economic effects are relatively limited. National policymakers should at least reconsider their arguments for relocation programs.

They should also carefully consider how these types of programs are conducted and implemented. There might be a positive effect of an increased percentage of state employees when combined with a larger municipality size, which could be explained by the ability of larger municipalities to create synergies through larger clusters (Porter 1998, 2000), often based on other knowledge-based institutions (Florida, 2005; Mellander and Florida, 2011). At least in the case of Norway, relocation programs and the establishment of new state jobs seem to be conceived as a compromise between the center and the periphery rather than as a thought-through strategy for local and regional development.

Finally, without wanting to dismiss the value of attracting more state employees to a municipality, which could have other advantages than purely economic ones, local actors should at least be conscious about the limited effects of this strategy for local development; at least if the strategy is not supported by thought-through, place-sensitive policies (Iammarino, et al., 2018; Rodríguez-Pose and Ketterer, 2019). However, there are some success stories. 
The quantitative data collected in this study could be used in a qualitative perspective to analyze why some municipalities have been able to use a high percentage of state employees to stimulate more business creation and to explore further the mechanisms that explain why there are more start-ups in university cities than in other municipalities. 


\section{References}

Abadie, A., Diamond, A., \& Hainmueller, J. (2015). Comparative politics and the synthetic control method. American Journal of Political Science, 59(2), pp. 495-510.

Acs, Z., \& Armington, C. (2004). Employment growth and entrepreneurial activity in cities. Regional studies, 38(8), pp. 911-927.

Arbeidsdepartementet. (2003). St.meld. nr. 17 (2002-2003) Om statlige tilsyn. Retrieved from https://www.regjeringen.no/no/dokumenter/stmeld-nr-17-2002-2003-/id134860/.

Arbo, P., \& Benneworth, P. (2007). Understanding the regional contribution of higher education institutions: A literature review. OECD Education Working Papers(9), p 1.

Audretsch, D. B. (1995). Innovation and industry evolution: Mit Press.

Audretsch, D. B., \& Fritsch, M. (1994). The geography of firm births in Germany. Regional studies, 28(4), pp. 359-365.

Audretsch, D. B., \& Fritsch, M. J. R. S. (2002). Growth regimes over time and space. 36(2), pp. 113-124.

Barro, R. J. (2001). Human capital and growth. American Economic Review, 91(2), pp. 12-17.

Benneworth, P., \& Nieth, L. (2018). The persistent problems of universities' contributions to regional development. RSA Regions(1)Retrieved from

https://regions.regionalstudies.org/ezine/article/the-persistent-problems-ofuniversities-contributions-to-regional-development-2/

Berry, C. R., \& Glaeser, E. L. (2005). The divergence of human capital levels across cities. Papers in regional science, 84(3), pp. 407-444.

Black, S. E., \& Lynch, L. M. (1996). Human-capital investments and productivity. The American economic review, 86(2), pp. 263-267.

Brakman, S., Garretsen, H., \& Van Marrewijk, C. (2009). The new introduction to geographical economics: Cambridge University Press.

Brett, A. M., Gibson, D. V., \& Smilor, R. W. (1991). University spin-off companies: Rowman \& Littlefield Publishers.

Burdett, K. (2012). Towards a theory of the labor market with a public sector. Labour Economics, 19(1), pp. 68-75. doi:https://doi.org/10.1016/j.labeco.2011.07.006 Retrieved from http://www.sciencedirect.com/science/article/pii/S0927537111000844

Candell, A. B., \& Jaffe, A. B. (1999). The regional economic impact of public research funding: a case study of Massachusetts. Industrializing knowledge: Universityindustry linkages in Japan and the United States, pp. 510-530.

Carree, M. A., \& Thurik, A. R. (2010). The impact of entrepreneurship on economic growth Handbook of entrepreneurship research (pp. 557-594): Springer.

Caves, R. (1998). Industrial organization and new findings on the turnover and mobility of firms. Journal of Economic Literature, 36(4), pp. 1947-1982.

Davidsson, P., Delmar, F., \& Wiklund, J. (2006). Entrepreneurship and the Growth of Firms: Edward Elgar Publishing.

Diener, E., \& Suh, E. (1997). Measuring quality of life: Economic, social, and subjective indicators. Social indicators research, 40(1-2), pp. 189-216.

Drucker, J., \& Goldstein, H. (2007). Assessing the regional economic development impacts of universities: A review of current approaches. International regional science review, 30(1), pp. 20-46.

Eckstein, H. (2000). Case study and theory in political science. In M. Hammersley, P. Floster \& R. Gomm (Eds.), Case study method (pp. 119-164). London: Sage.

Egeberg, M., \& Trondal, J. (2011). Agencification and location: Does agency site matter? Public Organization Review, 11(2), pp. 97-108. 
Elenius, L., Tjelmeland, H., Lähteenmäki, M., \& Golubev, A. (2015). The Barents Region: A Transnational History of Subarctic Northern Europe Oslo: Pax Forlag.

Eriksson, R., Lindgren, U., \& Malmberg, G. (2008). Agglomeration mobility: effects of localisation, urbanisation, and scale on job changes. Environment and Planning A, 40(10), pp. 2419-2434.

Etzkowitz, H., \& Leydesdorff, L. (2000). The dynamics of innovation: from National Systems and "Mode 2" to a Triple Helix of university-industry-government relations. Research policy, 29(2), pp. 109-123.

Faggio, G. (2016). Relocation of public sector workers: Evaluating a place-based policy.

Faggio, G., \& Overman, H. (2014). The effect of public sector employment on local labour markets. Journal of Urban Economics, 79, pp. 91-107.

Feller, I., Ailes, C. P., \& Roessner, J. D. (2002). Impacts of research universities on technological innovation in industry: evidence from engineering research centers. Research policy, 31(3), pp. 457-474.

Florida, R. (2005). Cities and the creative class Brooklyn: Routledge.

Foray, D., David, P. A., \& Hall, B. (2009). Smart specialisation-the concept. Knowledge economists policy brief, 9(85), p 100.

Fornyingsdepartementet. (2009). Evaluering av utflytting av statlig virksomhet. https://www.regjeringen.no/no/dokumenter/evaluering-av-utflytting-av-statligvirk/id566795/

Fulsås, N. (1993). Universitetet i Tromsø 25 år Tromsø: Universitetet i Tromsø.

Gabaix, X., \& Ioannides, Y. M. (2004). The evolution of city size distributions Handbook of regional and urban economics (Vol. 4, pp. 2341-2378): Elsevier.

George, A. L., \& Bennett, A. (2005). Case studies and theory development in the social sciences Cambridge MA: MIT Press.

Gerring, J. (2004). What is a case study and what is it good for? American Political Science Review, 98(2), pp. 341-354.

Goddard, J., \& Chatterton, P. (1999). Regional Development Agencies and the knowledge economy: harnessing the potential of universities. Environment and Planning C: Government and Policy, 17(6), pp. 685-699.

Hoyman, M., \& Faricy, C. (2009). It takes a village: A test of the creative class, social capital, and human capital theories. Urban Affairs Review, 44(3), pp. 311-333.

Iammarino, S., Rodriguez-Pose, A., \& Storper, M. (2018). Regional inequality in Europe: evidence, theory and policy implications. Journal of Economic Geography, 19(2), pp. 273-298. doi:10.1093/jeg/lby021 Retrieved from https://doi.org/10.1093/jeg/lby021

Jennings, W., \& Stoker, G. (2016). The bifurcation of politics: two Englands. The Political Quarterly, 87(3), pp. 372-382.

Kane, T. J. (2010). The importance of startups in job creation and job destruction.

Kiland, C., \& Trondal, J. (2010). Byråkrati og geografi-Geografisk relokalisering av norsk sentralforvaltning. Norsk statsvitenskapelig tidsskrift, 25(04), pp. 331-355.

Kommunaldepartementet. (2017). Meld. St. 18 (2016-2017) Berekraftige byar og sterke distrikt - Vedlegg. Retrieved from https://www.regjeringen.no/no/dokumenter/meld.st.-18-20162017/id2539348/.

Lee, N., Morris, K., \& Kemeny, T. (2018). Immobility and the Brexit vote. Cambridge Journal of Regions, Economy and Society, 11(1), pp. 143-163.

Leydesdorff, L. (2012). The triple helix, quadruple helix,..., and an N-tuple of helices: explanatory models for analyzing the knowledge-based economy? Journal of the Knowledge Economy, 3(1), pp. 25-35. 
Lijphart, A. (1979). Religious vs. linguistic vs. class voting: the "crucial experiment” of comparing Belgium, Canada, South Africa, and Switzerland. American Political Science Review, 73(02), pp. 442-458.

Lipset, S., \& Rokkan, S. (1967). Cleavage structures, party systems, and voter alignments: an introduction New York: Free Press.

Lyons, S. M. (2004). Well Placed to Deliver?: Shaping the Pattern of Government Service: Independent Review of Public Sector Relocation: HM Stationery Office.

Maskell, P. (2001). Towards a knowledge-based theory of the geographical cluster. Industrial and corporate change, 10(4), pp. 921-943.

McCann, P., \& Ortega-Argilés, R. (2011). Smart specialisation, regional growth and applications to EU cohesion policy. IEB Working Paper 2011/14

Mellander, C., \& Florida, R. (2011). Creativity, talent, and regional wages in Sweden. The Annals of Regional Science, 46(3), pp. 637-660.

Moretti, E. (2010). Local Multipliers. American Economic Review, 100(2), pp. 373-377. doi:doi: 10.1257/aer.100.2.373 Retrieved from http://www.aeaweb.org/articles?id=10.1257/aer.100.2.373

Moretti, E., \& Thulin, P. (2013). Local multipliers and human capital in the United States and Sweden. Industrial and corporate change, 22(1), pp. 339-362.

Norman, V. D., \& Venables, A. J. (2004). Industrial clusters: equilibrium, welfare and policy. Economica, 71(284), pp. 543-558.

NSD. (2018). The Norwegian State Administration Database. http://www.nsd.uib.no/polsys/en/civilservice/. Retrieved from http://www.nsd.uib.no/polsys/en/civilservice/

Pike, A., Rodríguez-Pose, A., \& Tomaney, J. (2007). What kind of local and regional development and for whom? Regional studies, 41(9), pp. 1253-1269.

Pinheiro, J., Bates, D., DebRoy, S., Sarkar, D., \& Team, R. C. (2013). nlme: Linear and nonlinear mixed effects models. $R$ package version, 3(1), p 111.

Porter, M. E. (1998). Clusters and the new economics of competition. Harvard Business Review Boston, 76(6)

Porter, M. E. (2000). Location, competition, and economic development: Local clusters in a global economy. Economic development quarterly, 14(1), pp. 15-34.

Reve, T. (2009). Norway-a global maritime knowledge hub.

Rodríguez-Pose, A. (2018). The revenge of the places that don't matter (and what to do about it). Cambridge Journal of Regions, Economy and Society, 11(1), pp. 189-209.

Rodríguez-Pose, A., \& Ketterer, T. (2019). Institutional change and the development of lagging regions in Europe. Regional studies, pp. 1-13. doi:10.1080/00343404.2019.1608356 Retrieved from https://doi.org/10.1080/00343404.2019.1608356

Rokkan, S. (1987). Centre-periphery structures in Europe: An ISSC workbook in comparative analysis Frankfurt Am Main: Campus Verlag.

Rokkan, S., \& Urwin, D. W. (1983). Economy, territory, identity: Politics of West European peripheries London: Sage Publications.

Saba, K. (2011). Koste hva det koste vil? Oppsummering av to relokaliseringsprosesser. In J. Trondal (Ed.), Byråkrati og geografi : geografisk relokalisering av norsk sentraladministrasjon. (pp. 27-58). Oslo: Universitetsforlaget.

Scott, A. J., \& Storper, M. (2005). Pathways to industrialization and regional development: Routledge.

Sheppard, E. (2011). Geography, nature, and the question of development. Dialogues in human geography, 1(1), pp. 46-75. 
Sjöstedt Landén, A. (2012). Moved by relocation: Professional identification in the decentralization of public sector jobs in Sweden (Umeå universitet.

Skodvin, O.-J. (1997). The reorganisation of non-university higher education in Norway: Problems and potentials. Tertiary Education and Management, 3(4), pp. 317-324.

Smilor, R. W., Gibson, D. V., \& Dietrich, G. B. (1990). University spin-out companies: technology start-ups from UT-Austin. Journal of business venturing, 5(1), pp. 63-76.

Steffensen, M., Rogers, E. M., \& Speakman, K. (2000). Spin-offs from research centers at a research university. Journal of business venturing, 15(1), pp. 93-111.

Stegmueller, D. (2013). How many countries for multilevel modeling? A comparison of frequentist and Bayesian approaches. American Journal of Political Science, 57(3), pp. 748-761.

Stein, J. (2019). The Striking Similarities between Northern Norway and Northern Sweden. Arctic Review on Law and Politics, 10, pp. 79-102. doi:10.23865/arctic.v10.1247 Retrieved from https://arcticreview.no/index.php/arctic/article/view/1247

Sætren, H. (1983). Iverksetting av offentlig politikk: En studie av utflytting av statsinstitusjoner fra Oslo 1960-1981 Oslo: Universitetsforlaget.

Sætren, H. (2011). Fra ord til handling. In J. Trondal (Ed.), Byråkrati og geografi : geografisk relokalisering av norsk sentraladministrasjon. (pp. 27-58). Oslo: Universitetsforlaget.

Teigen, H. (2011). Distriktspolitikkens historie: Frå nasjonal strategi til regional fragmentering? Plan, 43(06), pp. 48-54. Retrieved from http://www.idunn.no/plan/2011/06/art08

Trondal, J. (2011). Byråkrati og geografi : geografisk relokalisering av norsk sentraladministrasjon. Oslo: Universitetsforlaget.

Westlund, H. (2004). Regional effects of universities and higher education: a knowledge overview of Swedish, Scandinavian and international experiences. Stockholm: E. Gotab.

Wikhall, M. (2001). Universiteten och kompetenslandskapet: Effekter av den högre utbildningens tillväxt och regionala spridning i Sverige: Department of Social and Economic Geography, Lund University. 